\title{
Handwash versus hand-rub practices for preventing nosocomial infection in hospital intensive care units: A systematic review and meta-analysis
}

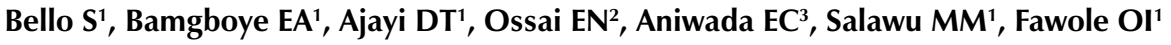 \\ 'Department of Epidemiology and Medical Statistics, Faculty of Public Health, College of Medicine, University of Ibadan, Nigeria \\ ${ }^{2}$ Department of Community Medicine, College of Health Sciences, Ebonyi State University Abakaliki, Nigeria \\ ${ }^{3}$ Department of Community Medicine, College of Medicine, University of Nigeria Enugu Campus, Nigeria
}

\section{Corresponding author:}

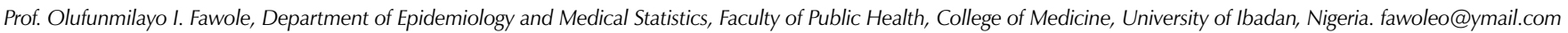

ABSTRACT:

Background: Compliance with handwashing in busy healthcare facilities, such as intensive care units (ICUs), is suboptimal and alcohol hand-rub preparations have been suggested to improve compliance. There is no evidence on the comparative effectiveness between handwash and hand-rub strategies. This systematic review was to assess the effectiveness of handwash versus hand-rub strategies for preventing nosocomial infection in ICUs.

\begin{abstract}
Methods Studies conducted in ICUs and indexed in PubMed comparing the clinical effectiveness and adverse events between handwash and hand-rub groups were included in a systematic review. The primary outcome was nosocomial infection rates. Secondary outcomes included microbial counts on healthcare providers' hands, mortality rates, patient/hospital cost of treatment of healthcare-associated infections (HCAIs), length of ICU/hospital stays, and adverse events. Studies were independently screened and data extracted by at least two authors. Meta-analyses of risk ratios (RR), incidence rate ratios (IRR), odds ratios (OR) and mean differences (MD), were conducted using the RevMan 5.3 software.
\end{abstract}

Results: Seven studies published between 1992-2009 and involving a total of 11,663 patients were included. Five studies (10,981 patients) contributed data to the ICUacquired nosocomial infection rates. The pooled IRR was $0.71\left(95 \% \mathrm{Cl} 0.61,0.82 ; \mathrm{I}^{2}=94 \%\right)$. On sensitivity analysis, pooled IRR was $0.39(95 \% \mathrm{Cl} 0.32,0.48 ; 4$ studies; 8,247 patients; $\mathrm{I}^{2}=0 \%$ ) in favour of hand rub. The pooled OR for mortality was $0.95\left(95 \% \mathrm{Cl} 0.78,1.61 ; 4\right.$ studies; 3,475 patients; $\left.\mathrm{I}^{2}=39 \%\right)$. The pooled MD for length of hospital stay was $-0.74\left(95 \% \mathrm{Cl}-2.83,1.34 ; 3\right.$ studies; 741 patients; $\left.\mathrm{I}^{2}=0 \%\right)$. The pooled OR for an undesirable skin effect was $0.37(95 \% \mathrm{Cl} 0.23,0.60 ; 3$ studies; 1504 patients; $I^{2}=0 \%$ ) in favour of hand rub. Overall quality of evidence was low.

Conclusion: Hand rub appeared more effective when compared to handwash in ICUs.

\section{KEYWORDS}

Nosocomial infection control; hand hygiene; intensive care units; healthcare-associated infection; hand washing; alcohol hand-rub preparations

\section{INTRODUCTION}

Nosocomial infections, or HCAls are infections occurring in patients during the process of care in hospital or other healthcare facilities, which were not present or incubating at the time of admission[1]. HCAls affect the quality of care and are the most frequent adverse consequence of healthcare worldwide[1]. Healthcare providers may also be affected by HCAls, or may serve as vector/source of infection for HCAls when they come into close contact with patients[1,2].

About seven in 100 hospitalised patients in developed countries and 15 in 100 hospitalised patients in developing countries will acquire at least one $\operatorname{HCAI}[3,4]$. Patients admitted to intensive care units (ICU) and neonates are particularly at risk of acquiring HCAls with over $30 \%$ of all patients admitted into ICU being affected by at least one HCAI in resource-constrained settings[3,4]. The risk of infection in ICU is increased with length of stay and use of invasive devices such as central venous lines, urinary catheters and ventilators[4]. While urinary tract infection is the leading cause of HCAls in high income countries, surgical wound infection is the most frequent HCAI in resource-poor settings[3, 4]. Data from the extensive work of the International Nosocomial Infection Control Consortium showed that device-associated nosocomial infection rates in ICUs were high in the Latin American countries[5-10]. For example, the overall device-associated rate was $29 \%$ in Brazil, $27 \%$ in Argentina and 24\% in Mexico[8-10]. Rates in Poland 
and Turkey were 24\%[11] and 34\%[12] respectively, while rates in Asia and Middle East countries were generally lower than 10\%[13-16], but higher than reported in the United States[17]. The mortality attributable to device-associated nosocomial infection ranged from $25 \%$ to $47 \%$ in Latin America[5, 6, 9], 4\% to $43 \%$ in Asia and the Middle East[13-15], and were as high as $75 \%$ in Morocco[18]. HCAls are the most frequent adverse consequence of unsafe patient care affecting both high income and resource-constrained settings.

HCAls exert considerable strain on healthcare resources especially the health workforce. They increase economic costs in treatments and unnecessary prolongation of patient hospital stays[6, 9, 12-15, 18-20]. Billions of dollars are expended annually in the treatment of HCAls and attendant disabilities worldwide[20]. Prolonged patient hospital stay due to HCAls in Europe alone is estimated at 16 million extra days per year[20]. A cost analysis of patients admitted into the ICU of a hospital in Brazil showed a ten-fold increase in the median cost of hospitalization per patient and a five-fold increase in the length of hospital stay among patients who acquired an HCAl compared to patients who did not[21]. Similar analysis of extra mean cost per patient incurred in treating central-line associated bloodstream infections in hospital ICU reported 5,000, and 11,500 US dollars in Argentina, and Mexico respectively[22, 23].

Hand hygiene has been considered to be the most effective tool in HCAls control ever since Ignaz Philipp Semmelweis observed its immense effect on the reduction of incidence of childbed fever[24]. Vigorous handwashing for 40-60 seconds, or the use of alcohol hand rub before and after every patient contact is recommended to prevent transmission of pathogenic organisms from one patient to the other[1]. Compliance is, however, often suboptimal in most resource-constrained settings because of limited infrastructure, a substantial workload and skin reactions to handwashing products[1]. Hand rub with alcohol is fast and may therefore improve compliance to hand hygiene recommendations in these settings[1], although, handwashing is indicated exclusively in certain instances, such as when the hands are visibly soiled. Although, hand rub has been recommended to improve compliance with hand hygiene recommendations[1], there is no synthesised evidence in clinical practice to demonstrate that hand-rub practices are as effective as handwash practices in preventing HCAls. Thus, the aim of this systematic review is to compare the clinical effectiveness of handwash with hand-rub practices in preventing HCAls in hospital ICUs.

\section{METHODS}

The study is a systematic review registered in PROSPERO with ID CRD42019119112 and was prepared according to the recommendations of the PRISMA statement[25].

\section{Study eligibility}

We included all study types, which compared handwash (with detergent or antiseptic) with hand-rub (with alcohol) strategies, provided they were conducted in an ICU in the review. Study groups with hand-rub strategies which permitted intermittent use of handwash for visibly soiled hands were also included because we recognised that such practices do occur in the real world. However, the number of handwash in the hand-rub group must be infrequent and insignificant when compared to the wholly handwash group. Studies could enrol patients of any age group admitted into an ICU, could be any type, including medical, surgical, neonatal or other. Studies that assessed outcomes among healthcare providers involved in ICU patients' care were also included. The primary outcome for the systematic review was HCAI rates. Secondary outcomes included microbial counts on healthcare providers' hands, mortality rates, patient/hospital cost of treatment of HCAls, length of ICU/hospital stay, and adverse events of the hand hygiene agents used.

\section{Search strategy and screening}

A search was conducted in PubMed. A sensitive search strategy was implemented using the core search strings, which included elements of (handwash* OR hand rub*) AND (hand hygiene agents) AND (outcomes) (Appendix). Screening of abstracts and titles was done in two stages. Two authors independently screened the abstracts and titles to select potentially relevant papers. A third author harmonised and confirmed eligibility of outputs from the first stage of screening and discussed doubts with a fourth author. Full texts of potentially eligible studies were retrieved and further assessed for eligibility.

\section{Data extraction}

A piloted data extraction form was used to extract data from included studies. Data was extracted by one author and checked by a second author. Data extracted included background study characteristics such as study reference, country where study was conducted, and study duration. Further detailed data extracted included a description of study design, sample size, country where study was conducted, study duration, study population, type of ICU, interventions conducted in study group(s), risk of bias (items from the Cochrane risk-of-bias tool such as method of randomisation), allocation concealment and type of blinding. Data was also extracted on whether study groups were comparable in terms of loss to follow-up and whether all participants were included in the analysis. Study outcomes corresponding to the pre-specified per-protocol outcomes were extracted for each study group. For dichotomous outcomes, number of events and the total for each study group were extracted. For measurement scale outcomes, the mean and standard deviation (SD) were extracted and if they were not provided, then the median and interquartile range $(\mathrm{IQR})$ were used. Rates in person-time of follow-up were extracted and when not available, the total person-time of follow up and the number of events were extracted.

\section{Data synthesis}

Data was analysed using the RevMan 5.2 software. Dichotomous outcomes, for example, mortality was presented as risk ratio (RR) with the hand-rub set as the experimental group and the handwash set as the control group. One study presented the mortality per 1,000 patientdays, but did not report the number of deaths, or the 
person-time of follow-up, hence this data was excluded. The number of deaths for each study group from the death rate and the total person-time of follow-up given per group were calculated. Measurement scale outcomes were presented as mean difference (MD). In one study where only median and IQR were reported, the mean and SD for each group were estimated. The person-time outcome of the rate of HCAI was presented as incidence rate ratio (IRR). The standard error for the natural log of IRR was calculated using the formula sqrt(1/ $e_{1}+1 / e_{2}$ ) where sqrt is square root and $e_{1}$ is the number of event in Group 1 and $e_{2}$ is the number of event in Group 2[26]. For all pooled analysis, we noted the direction of outcomes because the RevMan software by default recognises a higher number of events or a higher measurement as unfavourable. However, all outcomes were aligned with the default setting of the software.

For dichotomous outcomes, ORs were pooled. For measurement scale outcomes, MDs were pooled and for person-

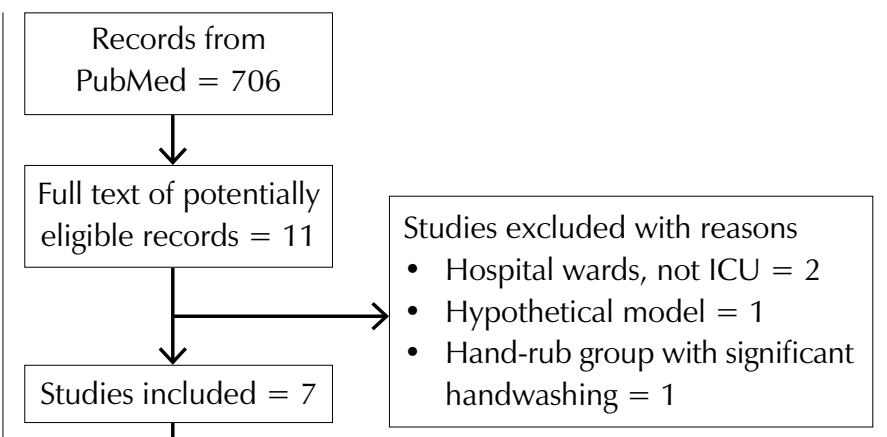

Studies included in quantitative synthesis $=5$

FIGURE 1: PRISMA flow chart of the screening process of the handwash vs. hand-rub strategy

\begin{tabular}{|c|c|c|c|c|c|c|c|}
\hline Design & $\begin{array}{l}\text { Sample } \\
\text { size }\end{array}$ & Country & Type of ICU & $\begin{array}{c}\text { Study } \\
\text { population* }\end{array}$ & $\begin{array}{l}\text { Handwash } \\
\text { system }\end{array}$ & Hand-rub system & Trial duration \\
\hline $\begin{array}{l}\text { Before-after } \\
\text { trial design }\end{array}$ & 175 & Italy & Neonatal ICU & Patients only & $\begin{array}{l}\text { Plain fluid } \\
\text { detergent } 0.5 \% \\
\text { triclosan }\end{array}$ & $\begin{array}{l}\text { Antiseptic detergent } \\
\text { preparation } 4 \% \\
\text { chlorhexidine gluconate } \\
\text { and alcohol-based } \\
\text { hand rub containing } \\
62 \% \text { denatured ethyl } \\
\text { alcohol** }\end{array}$ & $\begin{array}{c}16 \text { months } \\
\text { before; } \\
16 \text { months after }\end{array}$ \\
\hline $\begin{array}{l}\text { Cluster- } \\
\text { crossover } \\
\text { design }\end{array}$ & 1,894 & USA & $\begin{array}{l}\text { Adult critical care; } \\
\text { Surgical ICU; } \\
\text { Medical ICU; } \\
\text { cardiovascular ICU; }\end{array}$ & $\begin{array}{l}\text { Patients and } \\
\text { healthcare } \\
\text { providers }\end{array}$ & $\begin{array}{l}4 \% \text { solution of } \\
\text { chlorhexidine } \\
\text { gluconate }\end{array}$ & $\begin{array}{l}60 \% \text { isopropyl alcohol } \\
\text { hand-rising agent** }\end{array}$ & $\begin{array}{l}\text { Eight months; } \\
\text { mean hospital } \\
\text { stay } 3.4 \text { days }\end{array}$ \\
\hline $\begin{array}{l}\text { RCT parallel } \\
\text { group design }\end{array}$ & 23 & France & $\begin{array}{l}\text { Surgical and } \\
\text { medical ICU }\end{array}$ & $\begin{array}{l}\text { Healthcare } \\
\text { providers only }\end{array}$ & $\begin{array}{l}\text { Medicated } \\
\text { soap; } 4 \% \\
\text { chlorhexidine } \\
\text { gluconate }\end{array}$ & $\begin{array}{l}45 \% \text { 2-propanol, } 30 \% \\
\text { 1-propanol, } 0.2 \% \\
\text { mecetronium ethyl } \\
\text { sulphate }\end{array}$ & $\begin{array}{c}\text { Daily session } \\
\text { until target } \\
\text { activities were } \\
\text { met }\end{array}$ \\
\hline $\begin{array}{l}\text { RCT parallel } \\
\text { group design }\end{array}$ & 50 & USA & $\begin{array}{l}\text { Surgical ICU; } \\
\text { Medical ICU }\end{array}$ & $\begin{array}{l}\text { Healthcare } \\
\text { providers only }\end{array}$ & $\begin{array}{c}2 \% \\
\text { chlorhexidine } \\
\text { gluconate } \\
\text { containing } \\
\text { traditional } \\
\text { antiseptic wash }\end{array}$ & $\begin{array}{c}\text { Waterless hand rub } \\
\text { containing } 61 \% \text { ethanol } \\
\text { with emollients** }\end{array}$ & Four weeks \\
\hline $\begin{array}{l}\text { Before-after } \\
\text { trial design }\end{array}$ & 350 & France & $\begin{array}{l}\text { Multicentre adult } \\
\text { ICUs }\end{array}$ & $\begin{array}{l}\text { Patients and } \\
\text { healthcare } \\
\text { providers }\end{array}$ & $\begin{array}{c}\text { Either } 4 \% \\
\text { chlorhexidine } \\
\text { gluconate or } 4 \% \\
\text { povidone iodine }\end{array}$ & $\begin{array}{l}\text { 45\% isopropanol } \\
\text { (2-propanol, 30\% } \\
\text { 1-propanol, and 0.2\% } \\
\text { mecetronium ethyl } \\
\text { sulfate** }\end{array}$ & $\begin{array}{l}\text { Four months } \\
\text { before; } \\
\text { Two months } \\
\text { washout; } \\
\text { Four months } \\
\text { after }\end{array}$ \\
\hline
\end{tabular}

*Study population varied depending on outcomes assessed. For example, HCAl in patients and skin reaction in healthcare providers

**Additional provision for soap washing of visibly soiled hands 


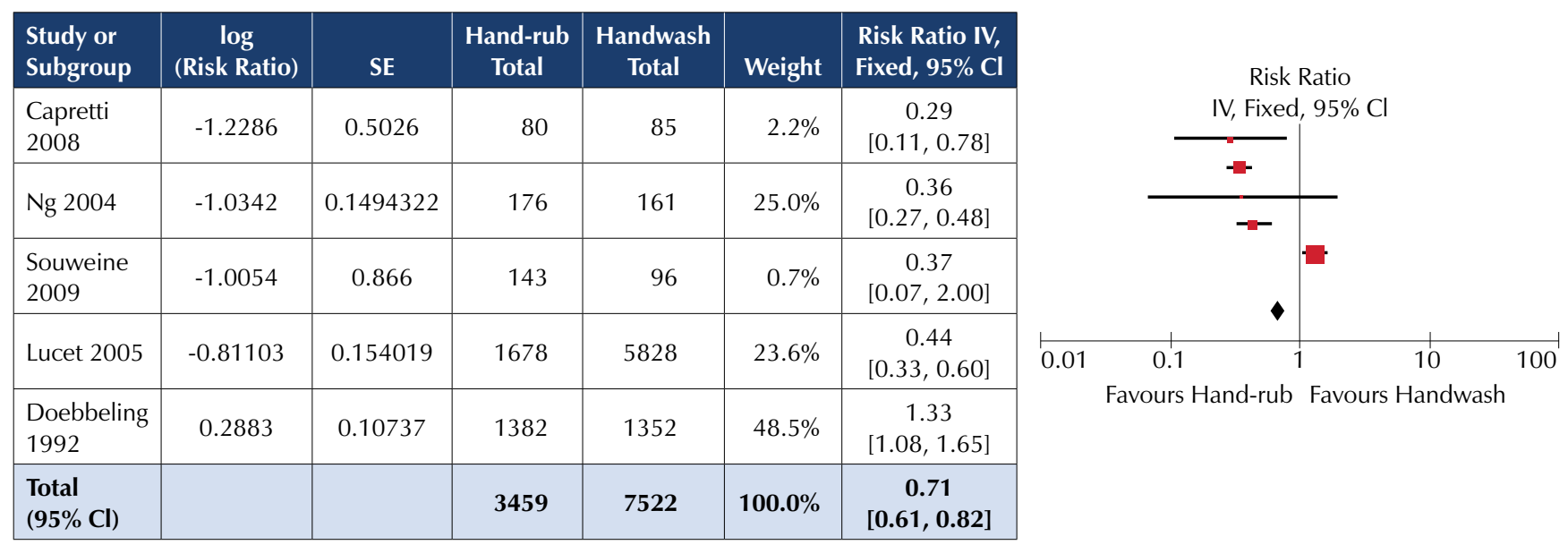

Heterogeneity: $\mathrm{Chi}^{2}=68.89, \mathrm{df}=4(\mathrm{P}<0.00002) ; \mathrm{I}^{2}=94 \%$

Test for overall effect: $Z=4.61(P<0.00001)$

FIGURE 2: Meta-analysis of incidence rate ratio for healthcare-associated infections

\begin{tabular}{|l|c|c|c|c|c|c|}
\hline $\begin{array}{l}\text { Study or } \\
\text { Subgroup }\end{array}$ & $\begin{array}{c}\mathbf{l o g} \\
\text { (Risk Ratio) }\end{array}$ & SE & $\begin{array}{c}\text { Hand-rub } \\
\text { Total }\end{array}$ & $\begin{array}{c}\text { Handwash } \\
\text { Total }\end{array}$ & Weight & $\begin{array}{c}\text { Risk Ratio IV, } \\
\text { Fixed, 95\% Cl }\end{array}$ \\
\hline $\begin{array}{l}\text { Capretti } \\
2008\end{array}$ & -1.2286 & 0.5026 & 80 & 85 & $4.3 \%$ & $\begin{array}{c}0.29 \\
{[0.11,0.78]}\end{array}$ \\
\hline Ng 2004 & -1.0342 & 0.1494322 & 176 & 161 & $48.6 \%$ & $\begin{array}{c}0.36 \\
{[0.27,0.48]}\end{array}$ \\
\hline $\begin{array}{l}\text { Souweine } \\
2009\end{array}$ & -1.0054 & 0.866 & 143 & 96 & $1.4 \%$ & $\begin{array}{c}0.37 \\
{[0.07,2.00]}\end{array}$ \\
\hline Lucet 2005 & -0.81103 & 0.154019 & 1678 & 5828 & $45.7 \%$ & $\begin{array}{c}0.44 \\
{[0.33,0.60]}\end{array}$ \\
\hline $\begin{array}{l}\text { Doebbeling } \\
1992\end{array}$ & 0.2883 & 0.10737 & 1382 & 1352 & $0.0 \%$ & $\begin{array}{c}1.33 \\
{[1.08,1.65]}\end{array}$ \\
\hline $\begin{array}{l}\text { Total } \\
\text { (95\% Cl) }\end{array}$ & & & $\mathbf{2 0 7 7}$ & $\mathbf{6 1 7 0}$ & $\mathbf{1 0 0 . 0 \%}$ & $\begin{array}{c}\mathbf{0 . 7 1} \\
{[\mathbf{0 . 6 1}, \mathbf{0 . 8 2}]}\end{array}$ \\
\hline
\end{tabular}

Risk Ratio

$\mathrm{IV}$, Fixed, 95\% Cl

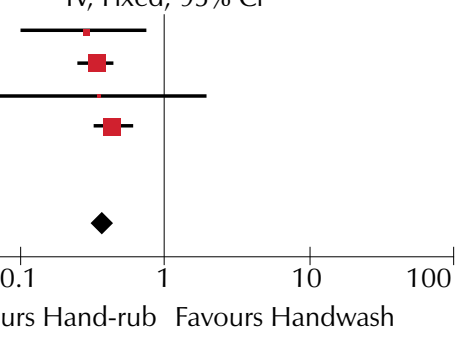

Heterogeneity: $\left.\mathrm{Chi}^{2}=1.43, \mathrm{df}=3(\mathrm{P}=0.70)\right) ; \mathrm{I}^{2}=0 \%$

Test for overall effect: $Z=9.03(P<0.00001)$

FIGURE 3: Sensitivity analysis, pooled incidence rate ratio for healthcare-associated infections of handwash vs. hand-rub strategy

time outcome, IRR was pooled. A fixed-effect model was adopted to pool outcomes from studies. Where there was a moderate to considerable statistical heterogeneity, this was investigated further by conducting a sensitivity analysis. Forest plots were used to summarise analyses. For outcomes that could not be pooled due to differences in assessment modalities between studies, a narrative synthesis was adopted to present the results.

\section{RESULTS}

The PubMed search conducted on March 21, 2018

(Appendix A), identified 706 abstracts from which 11 potentially eligible full texts were retrieved (Figure 1). Four full-text articles were excluded because two $[27,28]$ were conducted in regular hospital wards and not ICUs, one[29] had handwashing conducted in both groups in a similar way, while one study [30] was a hypothetical model that did not involve real-world data (Appendix B).
The sample sizes for the included studies[31-37] ranged between 23-7,994, published between 1992-2009 and involved a total of 11,663 participants. Three studies were conducted in France, two in the USA, one each in Italy and Hong Kong (Table 1). Study designs varied. Six were trials with different designs, while one was a retrospective observational design with historical control (Table 1). Two studies were carried out in neonatal ICUs, and five involved two or more types of ICUs, including surgical, medical, cardiovascular, and infectious diseases ICUs. Three studies enrolled patients only, two studies enrolled patients and healthcare providers, while two enrolled healthcare providers only. Chlorhexidine solution was used for handwashing in five studies, one study used triclosan, while one only mentioned "antiseptic soap" without stating the content. For the hand-rub groups, all were alcoholbased. Three studies contained alcohol only, two contained chlorhexidine in addition to alcohol, while two contained 


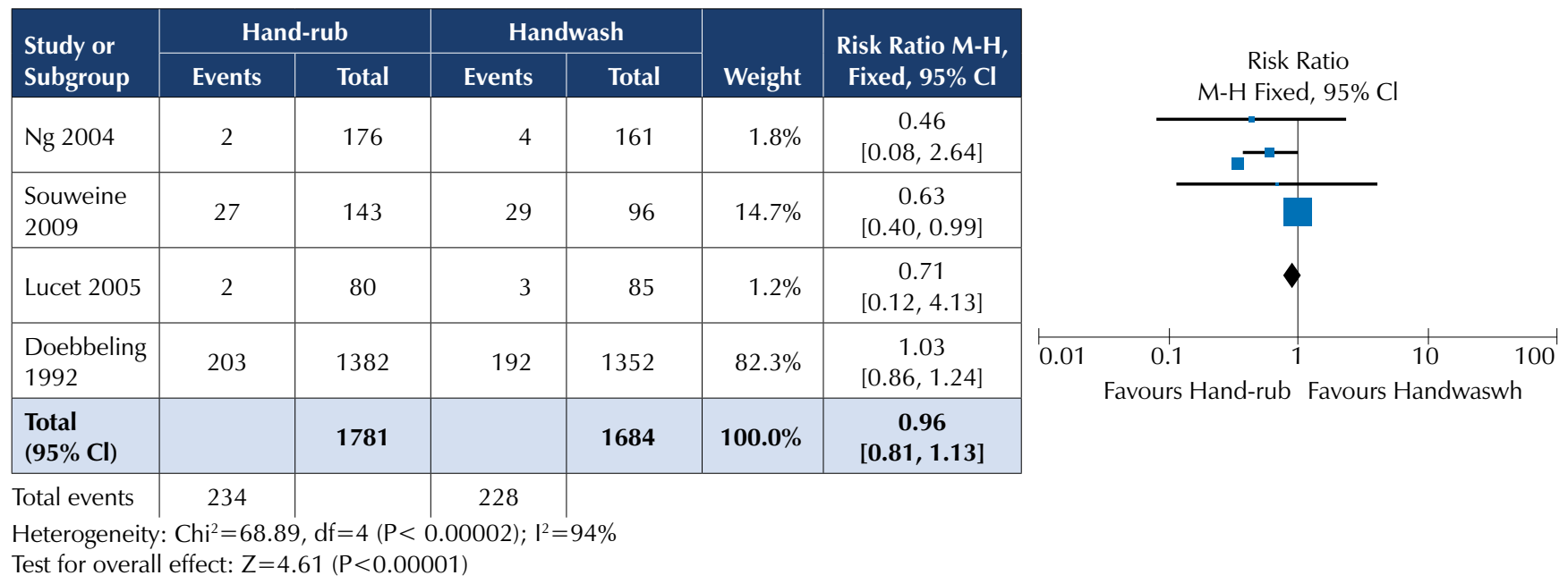

FIGURE 4: Meta-analysis of risk ratio for mortality of handwash vs. hand-rub strategy

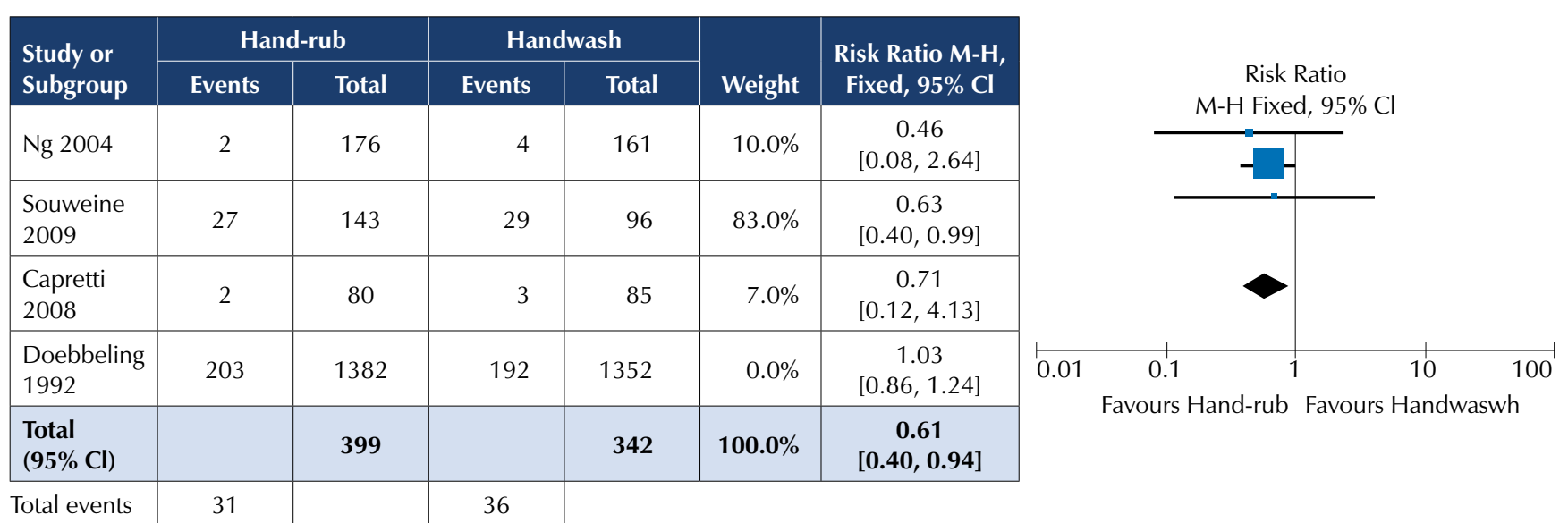

Heterogeneity: $\mathrm{Chi}^{2}=0.15, \mathrm{df}=2(\mathrm{P}=0.93) ; \mathrm{I}^{2}=0 \%$

Test for overall effect: $Z=2.23(P=0.03)$

FIGURE 5: Sensitivity analysis, pooled risk ratio for mortality of handwash vs. hand-rub strategy

mecetronium ethyl sulphate. In five of the studies, there were additional provision for occasional handwashing when hands were visibly soiled. The study durations ranged from a period of four weeks to five years.

\section{PRIMARY OUTCOME \\ ICU-acquired HCAI rates}

Five studies (10,981 patients) contributed data to the ICU-acquired HCAI rates. The pooled IRR was 0.71 (95\% confidence interval, $\mathrm{Cl}$ : 0.61 to 0.82 ), $\mathrm{I}^{2}=94 \%$ (Figure 2 ). Thus, on average, there was a $29 \%$ reduction in the rate of $\mathrm{HCAl}$ with the hand-rub strategy. However, the heterogeneity was considerable. Further investigation showed the heterogeneity was due to the qualitatively different study by Doebbeling et al [32] whose effect size was in favour of the handwash strategy. The study was less recent than the other four, and compliance with hand hygiene practices was found to be significantly higher in the handwash group compared to the hand-rub group. In a sensitivity analysis excluding this study, the pooled IRR for the remaining studies (four studies, 8,247 patients) was $0.39(95 \% \mathrm{Cl} 0.32,0.48), \mathrm{I}^{2}=0 \%$

(Figure 3).

\section{SECONDARY OUTCOMES \\ Mortality}

Four studies ( 3,475 patients) contributed data to the mortality outcome. The pooled OR was $0.95(95 \% \mathrm{Cl} 0.78,1.61) \mathrm{I}^{2}$ $=39 \%$ (Figure 4 ). Hence there was no significant difference in mortality between the two strategies and results had moderate heterogeneity. For consistency, the mortality outcome after excluding the Doebbeling et al study was also explored. The analysis (three studies, 741 patients) showed a pooled OR for mortality of $0.54(95 \% \mathrm{Cl} 0.31,0.93) \mathrm{I}^{2}=0 \%$ (Figure 5) hence a $46 \%$ reduction in the odds of dying from the use of the hand rub. The sensitivity analysis removed all the statistical heterogeneity. 


\begin{tabular}{|c|c|c|c|c|c|c|c|c|}
\hline \multirow{2}{*}{$\begin{array}{l}\text { Study or } \\
\text { Subgroup }\end{array}$} & \multicolumn{3}{|c|}{ Hand-rub } & \multicolumn{3}{|c|}{ Handwash } & \multirow[b]{2}{*}{ Weight } & \multirow{2}{*}{$\begin{array}{l}\text { Risk Ratio IV, } \\
\text { Fixed, } 95 \% \text { Cl }\end{array}$} \\
\hline & Mean & SD & Total & Mean & SD & Total & & \\
\hline $\begin{array}{l}\text { Capretti } \\
2008\end{array}$ & 51 & 27 & 80 & 54 & 34 & 85 & $5.0 \%$ & $\begin{array}{c}13.00 \\
{[-12.34,6.34]}\end{array}$ \\
\hline Ng 2004 & 77.7 & 45.2 & 176 & 79 & 58.5 & 161 & $3.5 \%$ & $\begin{array}{c}-1.30 \\
{[-12.54,9.94]}\end{array}$ \\
\hline $\begin{array}{l}\text { Souweine } \\
2009\end{array}$ & 7.9 & 85 & 143 & 8.5 & 8.4 & 96 & $91.5 \%$ & $\begin{array}{c}-0.60 \\
{[-2.78,1.58]}\end{array}$ \\
\hline $\begin{array}{l}\text { Total } \\
(95 \% \mathrm{Cl})\end{array}$ & & & 399 & & & 342 & $100.0 \%$ & $\begin{array}{c}-0.74 \\
{[-2.83,1.34]}\end{array}$ \\
\hline
\end{tabular}

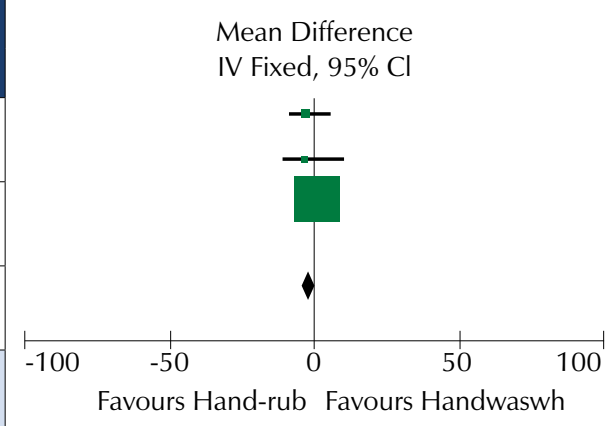

Heterogeneity: $\mathrm{Chi}^{2}=0.25, \mathrm{df}=2(\mathrm{P}=0.88) ; \mathrm{I}^{2}=0 \%$

Test for overall effect: $\mathrm{Z}=0.70(\mathrm{P}=0.48)$

FIGURE 6: Meta-analysis of mean difference in days for length of ICU stay of handwash vs. hand-rub strategy

\section{Length of ICU stay}

Four studies (3,475 patients) reported data on length of ICU stay. However, one did not report a measure of the variability for the mean. Thus, three studies (741 patients) were analysed for this outcome and they found a non-significant pooled MD $-0.74(95 \%$ $\mathrm{Cl}-2.83,1.34$ ) days $\mathrm{I}^{2}=0 \%$, in favour of the hand-rub strategy (Figure 6).

\section{Healthcare providers hand microbiology}

Three studies[32-34] (650 participants) assessed healthcare providers' hands for microorganism carriage. This variable was assessed differently by each study and therefore could not be pooled in a meta-analysis. Doebbeling et al [32] reported an average of 2.25 and 2.51 micro-organisms carriage per pair of hands in the handwash and hand-rub groups respectively. Girou et al, [33] assessed percentage reduction in the bacterial count and reported a difference between groups of $26 \%$ in favour of the hand-rub strategy. Larson et al, [34] assessed hand microbial counts in colony-forming units (CFU), but found no statistically significant difference between the handwash and the hand-rub groups when comparing change in CFU versus baseline.

\section{Adverse events}

Three studies (1,504 participants)[32, 34, 37] assessed adverse skin reactions in the use of hand agents. Two studies reported the total number of undesirable skin effects and these were pooled in a meta-analysis. The pooled OR of an undesirable skin condition was $0.37(95 \% \mathrm{Cl} 0.23,0.60) \mathrm{I}^{2}=0 \%$. Thus, on average, the use of the hand-rub strategy reduced the odds of an undesirable skin effect by about $63 \%$.

One study (50 participants) [(34] adopted the visual skin scaling (VSS) and the hand skin assessment (HSA). For both scales the higher the score, the better is the skin condition. Both the VSS and the HSA reported statistically significant difference in means in favour of the hand-rub strategy.

\section{STUDY QUALITY}

Only one study was a randomised controlled trial and used adequate means of allocation concealment [33] The same study adopted a blinded outcome assessment. One study [37] was deemed to have a degree of high risk of attrition bias because more than $10 \%$ of the study population was not accounted for in the outcome results. Thus, the overall quality of evidence was deemed to be low.

\section{DISCUSSION}

\section{Main findings}

The primary study outcome showed that hand-rub strategy significantly reduced the risk of HCAI in the ICU by at least $29 \%$. The reduction in risk was much higher at about $61 \%$ on average when the source of heterogeneity was eliminated. The sensitivity analysis also showed that hand-rub strategy reduced the odds of mortality by about $46 \%$ on average with no heterogeneity between studies, although the primary analysis showed no difference in mortality when there was moderate heterogeneity. The evidence, however, did not show a significant effect on length of stay in the ICU. One study further showed that the hand-rub strategy significantly reduced bacterial count on health workers' hands by about $26 \%$ on average, while another study found no difference between strategies in a similar hand microbiology assessment. The odds of an undesirable skin condition after use of the hand-hygiene strategy was also significantly reduced with the use of the hand-rub strategy by about $63 \%$ on average compared to use of the handwash strategy.

\section{Strengths and weaknesses}

The search was limited to only journals indexed in PubMed thus, there was a possibility of missing studies that had not been indexed in PubMed. However, any missing study may likely only have impact on the quantitative average, and not on the qualitative direction of effect. This is because all outcomes in the meta-analyses were consistently in favour of the hand-rub strategy in the qualitative direction of effect. This is the first study to synthesize the comparative evidence for the clinical effectiveness of the hand-rub strategy for preventing HCAls in ICUs even though several guidelines had recommended the use of this strategy to improve compliance with hand hygiene recommendations[1]. The evidence included a fairly large population of patients, which improved the robustness and 
precision of the meta-analyses results. One study with significant contamination of the hand-rub strategy with handwashing was excluded thus, the differential effect sizes may only be attributable to the difference in hand-hygiene strategies employed. The study has also not taken cognisance of withinstudy infection types. This is a common within-study variable to both handwash and hand-rub strategies.

Some variables may become important considerations considering the uncertainty around the randomisation of study participants in included studies. These may account for some of the differences in baseline susceptibilities to infection and the response to hand-hygiene practices. Some ICUs may not be comparable in terms of the rate of care contacts, for example, neonatal ICUs are expected to have higher rate of care contacts compared to adult ICUs. Similarly, surgical ICU patients may have a higher risk of infection compared to medical ICU patients. The frequency of hand hygiene may also influence HCAl rates and healthcare providers' skin conditions. Only one included study reported a significantly greater compliance with hand-rub strategy, but it is unclear whether the greater compliance with hand rub may partly or wholly account for differences in effect estimates between both strategies. Alcohol hand rubs appear generally friendlier to the hands compared to hand washing with soap and water. This could therefore, be a driver for compliance rather than a consequence of use.

\section{Mechanisms}

The findings from our study may be mediated through differences in the level of compliance with the hand-hygiene strategies. This was supported by the only study that showed a qualitatively different clinical effect on the HCAI rate, in favour of handwash strategy, thus causing significant statistical heterogeneity. The study assessed the level of compliance with hand-hygiene instructions, and found that it was significantly higher in the handwash group compared to the hand-rub group. However, the other studies included in the analysis did not assess compliance as an outcome thus, the postulation could not be investigated further. Studies suggests that handwashing with detergents or antiseptics generally require longer time than hand-rub practices[1, $30,37,38]$. Therefore, the general consensus is that handrub may improve compliance in most cases especially in overloaded and busy healthcare settings. A Cochrane review of interventions to improve hand-hygiene compliance in patient care examined whether an increase in hand hygiene compliance could reduce rates of HCAls. The review concluded that there was a lack of reliable evidence[39] to determine whether there was a clear effect.

The clinical effectiveness of the hand-rub strategy may also be partly explained by differences in the hand-rub agents. While all handwash preparations contained only one antiseptic, five of the seven included studies contained antiseptic in addition to the alcohol. Thus, there may be a synergistic protective effect of the antiseptic and the alcohol in hand-rub preparations. The number of studies were few, and therefore, did not allow for subgroup analysis by the number or type of antiseptic contained in the hand-hygiene preparations, or the type of ICUs where studies were conducted.

\section{Implications}

Findings from our study suggest that hand-rub strategies may be more effective than handwash strategies by acting through compliance. Improved compliance may be mediated through several factors, one of which could be favourable health workers' hand conditions demonstrated by reduced odds of a skin reaction with the use of hand-rub strategies. This suspicion, however, requires further study.

\section{CONCLUSION}

Our study demonstrated that hand rub appeared to be more effective than handwash as a hand-hygiene strategy, albeit with low-to-moderate quality evidence. This strategy supports the use of the hand-rub strategy in ICUs for positive clinical outcomes in patients and healthcare providers.

\section{REFERENCES}

1. World Health Organisation. WHO guidelines on hand hygiene in health care: a summary 2009 [Available from: https://www.who.int/gpsc/5may/tools/who_guidelineshandhygiene_summary.pdf.

2. Rothe C, Schlaich C, Thompson S. (2013). Healthcareassociated infections in sub-Saharan Africa. The Journal of Hospital Infection, 85(4),257-267. doi: 10.1016/j. jhin.2013.09.008.

3. Bagheri Nejad S, Allegranzi B, Syed SB, Ellis B, Pittet D. (2011). Health-care-associated infection in Africa: a systematic review. Bulletin of the World Health Organization, 89(10),757-765. doi: 10.2471/ BLT.11.088179.

4. Vincent JL, Bihari DJ, Suter PM, Bruining HA, White J, Nicolas-Chanoin MH, et al. (1995). The prevalence of nosocomial infection in intensive care units in Europe. Results of the European Prevalence of Infection in Intensive Care (EPIC) Study. EPIC International Advisory Committee. JAMA, 274(8),639-644.

5. Cuellar LE, Fernandez-Maldonado E, Rosenthal VD, Castaneda-Sabogal A, Rosales R, Mayorga-Espichan MJ, et al. (2008). Device-associated infection rates and mortality in intensive care units of Peruvian hospitals: findings of the International Nosocomial Infection Control Consortium. Revista Panamericana de Salud Publica $=$ Pan American Journal of Public Health, 24(1),16-24. doi: 10.1590/s102049892008000700002.

6. Guanche-Garcell H, Requejo-Pino O, Rosenthal VD, Morales-Perez C, Delgado-Gonzalez O, FernandezGonzalez D. (2011). Device-associated infection rates in adult intensive care units of Cuban university hospitals: International Nosocomial Infection Control Consortium (INICC) findings. International Journal of Infectious Diseases, 15(5),e357-362. doi: 10.1016/j. ijid.2011.02.001. 
7. Moreno CA, Rosenthal VD, Olarte N, Gomez WV, Sussmann O, Agudelo JG, et al. (2006). Device-associated infection rate and mortality in intensive care units of 9 Colombian hospitals: findings of the International Nosocomial Infection Control Consortium. Infection Control and Hospital Epidemiology, 27(4),349-356. doi: 10.1086/503341.

8. Ramirez Barba EJ, Rosenthal VD, Higuera F, Oropeza MS, Hernandez HT, Lopez MS, et al. (2006). Device-associated nosocomial infection rates in intensive care units in four Mexican public hospitals. American Journal of Infection Control, 34(4),244-247. doi: 10.1016/j.ajic.2005.05.024.

9. Rosenthal VD, Guzman S, Orellano PW. (2003). Nosocomial infections in medical-surgical intensive care units in Argentina: attributable mortality and length of stay. American Journal of Infection Control, 31(5),291-295. doi: 10.1067/ mic.2003.1.

10. Salomao R, Rosenthal VD, Grimberg G, Nouer S, Blecher S, Buchner-Ferreira S, et al. (2008). Device-associated infection rates in intensive care units of Brazilian hospitals: findings of the International Nosocomial Infection Control Consortium. Revista Panamericana de Salud Publica = Pan American Journal of Public Health, 24(3),195-202. doi: 10.1590/s1020-49892008000900006.

11. Leblebicioglu $H$, Rosenthal VD, Arikan OA, Ozgultekin A, Yalcin AN, Koksal I, et al. (2007). Device-associated hospital-acquired infection rates in Turkish intensive care units. Findings of the International Nosocomial Infection Control Consortium (INICC). The Journal of Hospital Infection, 65(3),251-257. doi: 10.1016/j.jhin.2006.10.012.

12. Kubler A, Duszynska W, Rosenthal VD, Fleischer M, Kaiser T, Szewczyk E, et al. (2012). Device-associated infection rates and extra length of stay in an intensive care unit of a university hospital in Wroclaw, Poland: International Nosocomial Infection Control (INICC) findings. Journal of Critical Care, 27(1),105.e5-10. doi: 10.1016/j. jcrc.2011.05.018.

13. Hu B, Tao L, Rosenthal VD, Liu K, Yun Y, Suo Y, et al. (2013). Device-associated infection rates, device use, length of stay, and mortality in intensive care units of 4 Chinese hospitals: International Nosocomial Control Consortium findings. American Journal of Infection Control, 41(4),301306. doi: 10.1016/j.ajic.2012.03.037.

14. Kanj S, Kanafani Z, Sidani N, Alamuddin L, Zahreddine N, Rosenthal V. (2012). International nosocomial infection control consortium findings of device-associated infections rate in an intensive care unit of a Lebanese university hospital. Journal of Global Infectious Diseases, 4(1),15-21. doi: 10.4103/0974-777X.93755.

15. Mehta A, Rosenthal VD, Mehta Y, Chakravarthy M, Todi SK, Sen N, et al. (2007). Device-associated nosocomial infection rates in intensive care units of seven Indian cities. Findings of the International Nosocomial Infection Control Consortium (INICC). The Journal of Hospital Infection, 67(2),168-174. doi: 10.1016/j. jhin.2007.07.008.
16. Tao L, Hu B, Rosenthal VD, Gao X, He L. (2011). Deviceassociated infection rates in 398 intensive care units in Shanghai, China: International Nosocomial Infection Control Consortium (INICC) findings. International Journal of Infectious Diseases, 15(11):e774-780. doi: 10.1016/j.ijid.2011.06.009.

17. Magill SS, Hellinger W, Cohen J, Kay R, Bailey C, Boland B, et al. (2012). Prevalence of healthcare-associated infections in acute care hospitals in Jacksonville, Florida. Infection Control and Hospital Epidemiology, 33(3),283-291. doi: 10.1086/664048.

18. Madani N, Rosenthal VD, Dendane T, Abidi K, Zeggwagh AA, Abouqal R. (2009). Health-care associated infections rates, length of stay, and bacterial resistance in an intensive care unit of Morocco: findings of the International Nosocomial Infection Control Consortium (INICC). International Archives of Medicine, 2(1),29. doi: 10.1186/1755-7682-2-29.

19. Barnett AG, Graves N, Rosenthal VD, Salomao R, RangelFrausto MS. (2010). Excess length of stay due to central line-associated bloodstream infection in intensive care units in Argentina, Brazil, and Mexico. Infection Control and Hospital Epidemiology, 31(11),1106-1114. doi: 10.1086/656593.

20. World Health Organisation. The burden of health careassociated infection worldwide 2010 Retrieved from https://www.who.int/gpsc/country_work/gpsc_ccisc_fact sheet_en.pdf.

21. Nangino Gde O, Oliveira CD, Correia PC, Machado Nde M, Dias AT. (2012). Financial impact of nosocomial infections in the intensive care units of a charitable hospital in Minas Gerais, Brazil. Revista Brasileira de Terapia Intensiva, 24(4),357-361. doi: 10.1590/s0103$507 \times 2012000400011$.

22. Higuera F, Rangel-Frausto MS, Rosenthal VD, Soto JM, Castanon J, Franco G, et al. (2007) Attributable cost and length of stay for patients with central venous catheterassociated bloodstream infection in Mexico City intensive care units: a prospective, matched analysis. Infection Control and Hospital Epidemiology, 28(1),31-35. doi: 10.1086/510812.

23. Rosenthal VD, Guzman S, Migone O, Crnich CJ. (2003). The attributable cost, length of hospital stay, and mortality of central line-associated bloodstream infection in intensive care departments in Argentina: A prospective, matched analysis. American Journal of Infection Control, 31(8),475480. doi: 10.1016/j.ajic.2003.03.002.

24. Kampf G, Kramer A. (2004). Epidemiologic background of hand hygiene and evaluation of the most important agents for scrubs and rubs. Clinical Microbiology Reviews, 17(4),863-893. doi: 10.1128/CMR.17.4.863-893.2004.

25. Liberati A, Altman DG, Tetzlaff J, Mulrow C, Gotzsche PC, loannidis JP, et al. (2009). The PRISMA statement for reporting systematic reviews and meta-analyses of studies that evaluate healthcare interventions: explanation and elaboration. British Medical Journal, 339,b2700. doi: 10.1136/bmj.b2700. 
26. Spittal MJ, Pirkis J, Gurrin LC. (2015). Meta-analysis of incidence rate data in the presence of zero events. BMC Medical Research Methodology, 15,42. doi: 10.1186/ s12874-015-0031-0.

27. Ho HJ, Poh BF, Choudhury S, Krishnan P, Ang B, Chow A. (2015). Alcohol handrubbing and chlorhexidine handwashing are equally effective in removing methicillinresistant Staphylococcus aureus from health care workers' hands: A randomized controlled trial. American Journal of Infection Control, 43(11),1246-1248. doi: 10.1016/j. ajic.2015.06.005.

28. Kampiatu P, Cozean J. (2015). A controlled, crossover study of a persistent antiseptic to reduce hospital-acquired infection. African Journal of Infectious Diseases, 9(1),6-9. doi: 10.4314/ajid.v9i1.2.

29. Larson E, Silberger M, Jakob K, Whittier S, Lai L, Della Latta P, et al. (2000). Assessment of alternative hand hygiene regimens to improve skin health among neonatal intensive care unit nurses. Heart \& lung : the Journal of Critical Care, 29(2), 136-142.

30. Voss A, Widmer AF. (1997). No time for handwashing!? Handwashing versus alcoholic rub: can we afford $100 \%$ compliance? Infection Control and Hospital Epidemiology, 18(3),205-208. doi: 10.1086/647590.

31. Capretti MG, Sandri F, Tridapalli E, Galletti S, Petracci E, Faldella G. (2008). Impact of a standardized hand hygiene program on the incidence of nosocomial infection in very low birth weight infants. American Journal of Infection Control, 36(6),430-435. doi: 10.1016/j.ajic.2007.10.018.

32. Doebbeling BN, Stanley GL, Sheetz CT, Pfaller MA, Houston AK, Annis L, et al. (1992). Comparative efficacy of alternative hand-washing agents in reducing nosocomial infections in intensive care units. The New England Journal of Medicine, 327(2),88-93. doi: 10.1056/ NEJM199207093270205.
33. Girou E, Loyeau S, Legrand P, Oppein F, Brun-Buisson C. (2002). Efficacy of handrubbing with alcohol based solution versus standard handwashing with antiseptic soap: randomised clinical trial. British Medical Journal, 325(7360),362. doi: 10.1136/bmj.325.7360.362.

34. Larson EL, Aiello AE, Bastyr J, Lyle C, Stahl J, Cronquist A, et al. (2005). Assessment of two hand hygiene regimens for intensive care unit personnel. Critical Care Medicine, 29(5),944-951. doi: 10.1097/00003246-200105000-00007.

35. Lucet JC, Paoletti X, Lolom I, Paugam-Burtz C, Trouillet JL, Timsit JF, et al. (2005). Successful long-term program for controlling methicillin-resistant Staphylococcus aureus in intensive care units. Intensive Care Medicine, 31(8),10511057. doi: 10.1007/s00134-005-2679-0.

36. Ng PC, Wong HL, Lyon DJ, So KW, Liu F, Lam RK, et al. (2004). Combined use of alcohol hand rub and gloves reduces the incidence of late onset infection in very low birthweight infants. Archives of Disease in Childhood Fetal and Neonatal Edition, 89(4),F336-340. doi: 10.1136/ adc.2003.031104.

37. Souweine B, Lautrette A, Aumeran C, Benedit M, Constantin JM, Bonnard M, et al. (2009). Comparison of acceptability, skin tolerance, and compliance between handwashing and alcohol-based handrub in ICUs: results of a multicentric study. Intensive Care Medicine, 35(7),12161224. doi: 10.1007/s00134-009-1485-5.

38. Hugonnet S, Perneger TV, Pittet D. (2002). Alcoholbased handrub improves compliance with hand hygiene in intensive care units. Archives of Internal Medicine, 162(9),1037-1043. doi: 10.1001/archinte.162.9.1037.

39. Gould DJ, Moralejo D, Drey N, Chudleigh JH, Taljaard M. (2017). Interventions to improve hand hygiene compliance in patient care. The Cochrane Database of Systematic Reviews, 9(9),CD005186. doi: 10.1002/14651858. CD005186.pub4. 